Tiina LINNAS, Aili KOGERMAN, H. HEINLO, O. KIRRET

\title{
REACTION OF HYDROXYALKYL METHACRYLATE GELS WITH CHLORINE DERIVATES OF TRIAZINE
}

Of the carriers for affinity chromatography, the synthetic macroporous polymer hydrogels based on copolymers of glycol methacrylate with glycol dimethacrylate are of great interest. These gels exhibit a remarkable chemical and mechanical stability. Affinants can be bound to hydroxyl groups of gel with cyanogen bromide by using a method analogical to that of binding the affinant to Sepharose ["].

The method of binding biologically active molecules to HMG (hydroxyalkyl methacrylate gels) with cyanogen bromide has several disadvantages, toxicity of the reagents used being one of them. We have found that the binding of biologically active molecules to the $-\mathrm{OH}$ groups of HMG may be regarded possible when less toxic reagents TCT (2,4,6-trichlortriazine) and DCT (2-amino-4,6-dichlortriazine) are used.

The objective of this work was to investigate the binding of trypsin to the above-mentioned gels by the aid of chlorine derivates of triazine and to demonstrate the use of immobilized trypsin in the isolation of trypsin antibody from rabbit serum immunized with a suspension of tissue antigens of pancreas extract [ $\left.{ }^{2}\right]$.

\section{Material and methods}

Enzymes. Bovine trypsin (EC 3.4.4.4) «B» was obtained from the Olaine Works (U.S.S.R.). Esterolytic activity of trypsin was 23 ( $\mu$ moles-min) $\cdot \mathrm{mg}$ and immobilized trypsin was assayed with BAEE (N-benzoyl-L-arginine ethylester) at $25^{\circ} \mathrm{C}$ with the pHstat method.

Chemicals. Two hydroxyalkyl methacrylate gels, produced and marked under the trade mark Spheron from LACHEMA Company (Brno, Czechoslovakia), were used: basic Spheron P-1000 (particle size 0.063 to $0.100 \mathrm{~mm}$ ) and Spheron C-1000 (particle size 0.040 to $0.060 \mathrm{~mm}$ ) containing $p$-nitrophenylester groups $0.095 \mathrm{~m} \cdot \mathrm{eqv} / \mathrm{g}$ and $-\mathrm{COOH}-$ groups $0.2 \mathrm{~m} \cdot \mathrm{eqv} / \mathrm{g}$. BAEE. $\mathrm{HCl}$ and Hammarsten casein were from Reanal (Hungary). TCT (analytical grade) used was a product of the Yerevan Chemical Works and DCT was synthesized in our laboratory by the method described by G. Kay and M. D. Lilly [ ${ }^{3}$ ].

Activating HMG with chiorine derivates of triazine. In order to activate HMG with TCT or DCT, the following method was used: $1 \mathrm{~g}$ of HMG was activated with $20 \mathrm{ml}$ of 1 to $3 \mathrm{~N} \mathrm{NaOH}$ solution for $15 \mathrm{~min}$. Then the solution of $\mathrm{NaOH}$ was sucked off and $50 \mathrm{ml}$ of a $2 \%$ solution of TCT in a mixture of xyloldioxane $(1: 1)$ or $50 \mathrm{ml}$ of DCT in acetone or benzene were added to the product. The reaction was carried out at room temperature. The product obtained was sucked off, washed with a mixture of water-dioxane-acetic acid $(1 ; 1 ; 1)$, with water and acetone, and dried under vacuum. 
The reaction product was assayed $(\mathrm{H}, \mathrm{C}, \mathrm{N})$ on a Hewlett-Packard automatic analyzer. The chlorine content was determined by potentiometric titration.

B ind ing trypsin to S pheron. The binding of trypsin to Spheron P-1000 activated with chlorine derivates of triazine was carried out in $0.2 \mathrm{M} \mathrm{H}_{3} \mathrm{BO}_{3} / \mathrm{Na}_{2} \mathrm{CO}_{3}$ buffer at $23^{\circ}$. The binding reaction was broken off by rapid acidification of samples with $\mathrm{pH}$ adjusted to 2.5-3.0. After that the samples were washed with tris-buffer.

The binding of trypsin to Spheron C-1000 proceeded as follows: a certain amount of Spheron was stirred in a ten-fold excess of water and stored in a refrigerator for swelling for 2 to $3 \mathrm{~h}$. The swollen gel was filtered, transferred to a phosphate buffer $(\mathrm{pH} 7.0)$ containing about $200 \mathrm{mg}$ of trypsin per $1 \mathrm{~g}$ of dry gel, and shaken for $60 \mathrm{~min}$ at $20^{\circ}$.

Unnecessary valency groups were washed off with a $1 \mathrm{M}$ solution of ethanolamine in $0.2 \mathrm{M}$ phosphate buffer ( $\mathrm{pH} 8.0$ ), nonspecific enzyme was removed from column by washing alternately in $0.2 \mathrm{M}$ phosphate buffer $(\mathrm{pH} 8.0$ ) containing $1 \mathrm{M} \mathrm{NaCl}$, and in $0.2 \mathrm{M}$ acetate buffer (pH 4.0) containing $1 \mathrm{M} \mathrm{NaCl}$.

Determination of trypsin antibodies. The amount of antibodies in rabbit serum immunized with a suspension of tissue antigens of pancreas was determined in the column $(0.5 \times 10 \mathrm{~cm})$ packed with Spheron P-1000 with immobilized trypsin. To assay the quantity of antibodies, $1 \mathrm{mg}$ of serum was introduced into the column with an immunosorbent. After 15 min of incubation with a physiological solution at $\mathrm{pH} 7.4$, the nonspecific proteins were washed out, and at $\mathrm{pH} 3.2$ the specific ories. The quantity of protein was determined at the absorption of $280 \mathrm{~nm}$.

\section{Results and discussion}

Products found as a result of the activation reaction of HMG with TCT and DCT are shown in Scheme.

The presence of two or three reactive chlorine atoms in the molecule of chlorine-substituted triazines leads to the fonmation of monosubstituted ester of triazine or the substitution for the second chlorine atom in the molecule of triazine, thus giving rise to the formation of absolutely undesirable intermolecular bonds according to scheme II.

Data in the Table show that reaction of HMG with TCT proceeds mainly according to scheme II, i. e., the second chlorine atom is sufficiently reactive

Reaction of chlorine derivates of triazine with $\mathrm{HMG}$

\begin{tabular}{c|c|c|c|c}
\hline $\mathrm{N}$ & $\begin{array}{l}\text { Tria- } \\
\text { zine }\end{array}$ & $\begin{array}{c}\mathrm{N}, \\
\%\end{array}$ & $\begin{array}{c}\mathrm{Cl} \\
\%\end{array}$ & $\begin{array}{c}\text { Activity } \\
\text { of trypsin, } \\
\text { U/g }\end{array}$ \\
\hline
\end{tabular}

\begin{tabular}{c|cccc}
1 & TCT & 5.15 & 4.66 & \multicolumn{1}{l}{85} \\
2 & TCT & 3.01 & 2.80 & 90 \\
3 & TCT & 3.66 & 4.20 & 69.60 \\
4 & DCT & 2.21 & 1.20 & 84.00 \\
5 & DCT & 2.30 & 1.20 & 160.00 \\
6 & DCT & 0.56 & 0.39 & 100.00 \\
7 & DCT & 0.20 & 0.15 & 70.00 \\
8 & DCT & 8.47 & 3.05 & 81.20 \\
9 & DCT & 9.90 & 4.38 & 73.90 \\
10 & DCT & 7.10 & 2.34 & 91.30 \\
$11 *$ & - & - & - & 42.00
\end{tabular}

* Spheron C-1000 for binding trypsin containing $p$-nitrophenyl. ester groups. and the reaction products obtained contain additional intermolecular bonds. In the reaction of HMG with DCT the substitution reaction proceeds mainly according to scheme I, i. e., the second chlorine atom is considerably less reactive and the formation of additional intermolecular bonds is insignificant. Varying reaction conditions, i. e., decreasing the reaction time, it is possible to obtain a gel without additional bonds.

As can be seen from Table, trypsin bound to Spheron C-1000 is of low reactivity and therefore will not find use in practice.

In order to optimize the binding conditions of biologically active molecules to HMG activated with chlorine derivates of triazine, trypsin has been used as a model compound. 


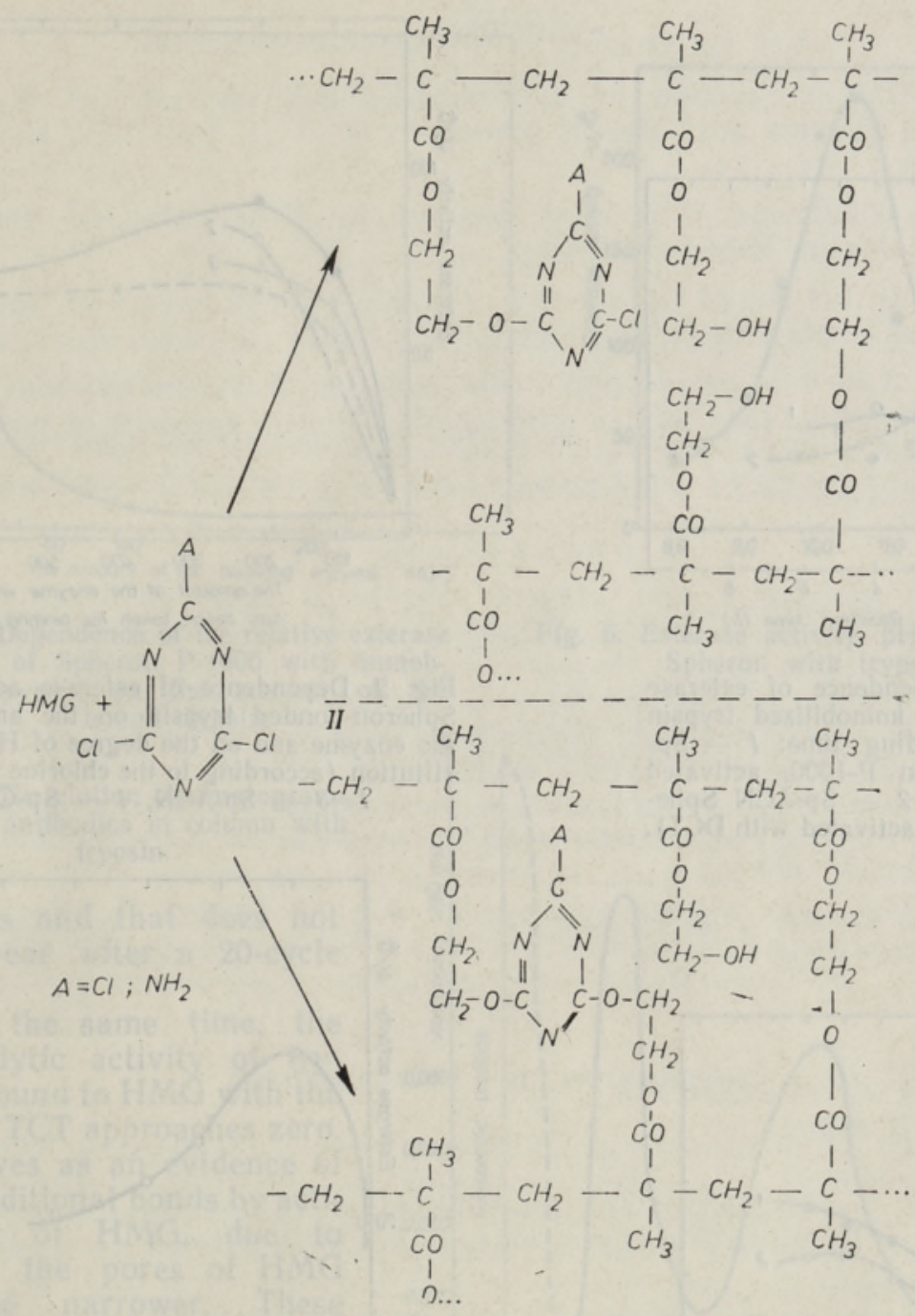

The dependence of the esterase activity of bound trypsin on the reaction time (Fig. 1), the ratio of trypsin to HMG (Fig. 2) and the $\mathrm{pH}$ of the medium (Fig. 3) have been studied. Investigations show that the esterase activity of trypsin increases insignificantly after the 2-hours reaction time, although the general amount of the bound protein increases at the same time.

An increase in the ratio of trypsin to HMG by more than $2-10$ is impossible because although the amount of the ferment bound to the matrix increases, the increase in the ratio of trypsin to HMG gives no considerable increase in the activity of trypsin. The binding of trypsin should be carried out in a phosphate buffer at $\mathrm{pH} 9$ (Fig. 4) and at a ratio of trypsin to HMG of $2: 10$ for $2 \mathrm{~h}$.

The activity of trypsin bound to HMG is directly dependent on the degree of the $-\mathrm{OH}$ group substitution of $\mathrm{HMG}$ (i. e., on the chlorine content in the molecule) (Fig. 5).

The best results have been obtained by binding trypsin to the comparati- 


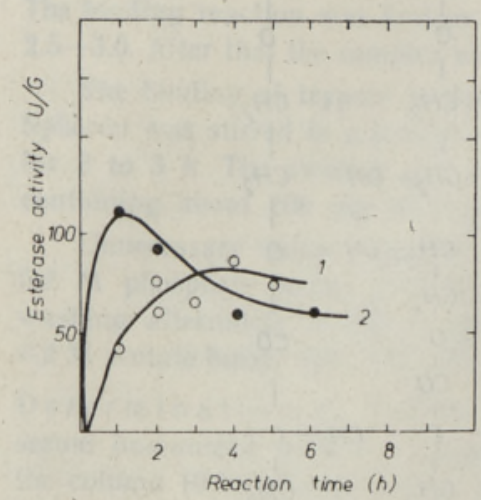

Fig. 1. Dependence of esterase activity of immobilized trypsin on the binding time: $1-\mathrm{Sp}$ CN (Spheron P-1000, activated with TCT), 2 - Sp-ACN Spheron P-1000, activated with DCT).

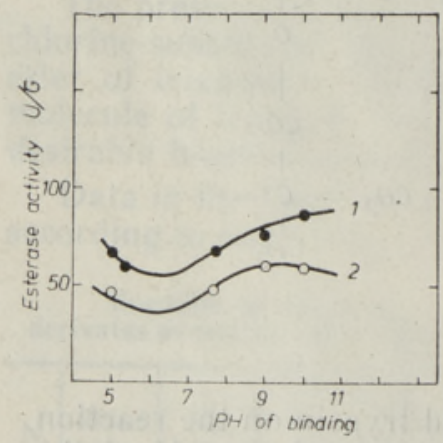

Fig. 3. Dependence of esterase activity of immobilized trypsin on $\mathrm{pH}$ of the medium: $1-\mathrm{Sp}-\mathrm{CN}, 2-\mathrm{Sp}-\mathrm{ACN}$.

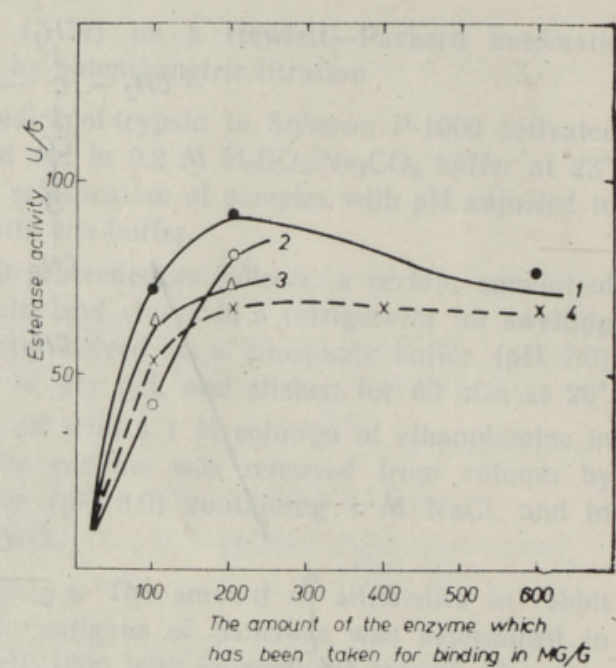

Fig. 2. Dependence of esterase activity of Spheron-bonded trypsin on the amount of the enzyme and on the degree of HMG substitution (according to the chlorine content): $1-3-\mathrm{Sp}-\mathrm{ACN}, 4-\mathrm{Sp}-\mathrm{CN}$.

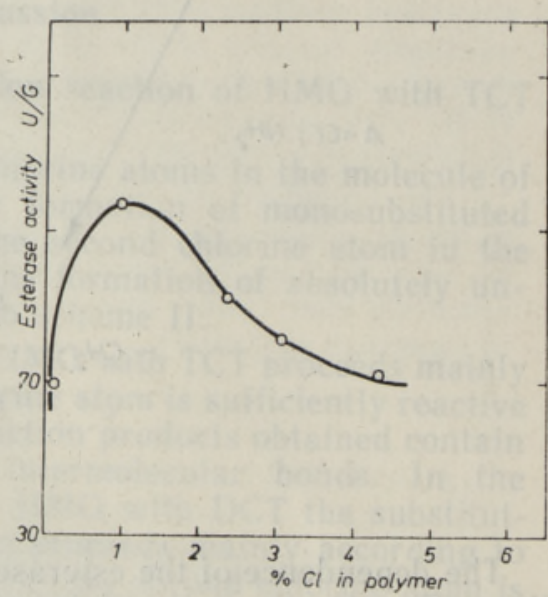

Fig. 4. Dependence of esterase activity of immobilized trypsin on the chlorine content of Spheron.

vely less substituted HMG containing about $1 \%$ chlorine. The activity of bound trypsin decreases considerably with the increase of the chlorine content in HMG from 1 to $5 \%$. The amount of the enzyme bound to the polymer matrix increases with the increase in the reaction time and the degree of the HMG substitution. We have demonstrated that the comparative activity of bound trypsin depends on the amount of trypsin bound to the polymer matrix so that the relative activity of the bound enzyme decreases considerably with an increase in its amount (Fig. 6).

All of the samples of HMG which have been activated with either TCT or DCT have excellent esterase activity that they retain during several 

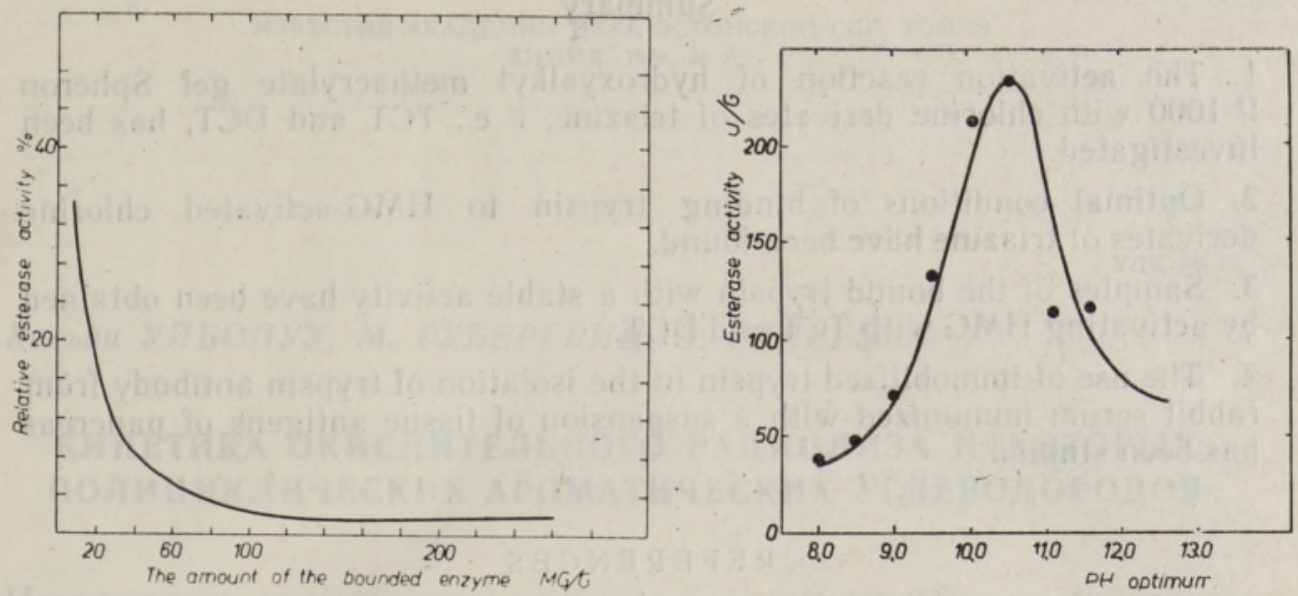

Fig. 5. Dependence of the relative esterase activity of Spheron P-1000 with immobilized trypsin on the amount of the

Fig. 6. Esterase activity. pH optimum of Spheron with trypsin.

Fig. 7. The elution chromatogramme for antibodies in column with trypsin.

months and that does not disappear after a 20-cycle work.

At the same time, the proteolytic activity of trypsin bound to HMG with the aid of TCT approaches zero. It serves as an evidence of the additional bonds by activation of $\mathrm{HMG}$, due to which the pores of HMG become narrower. These pores, although accessible to the comparatively small molecule of trypsin and its

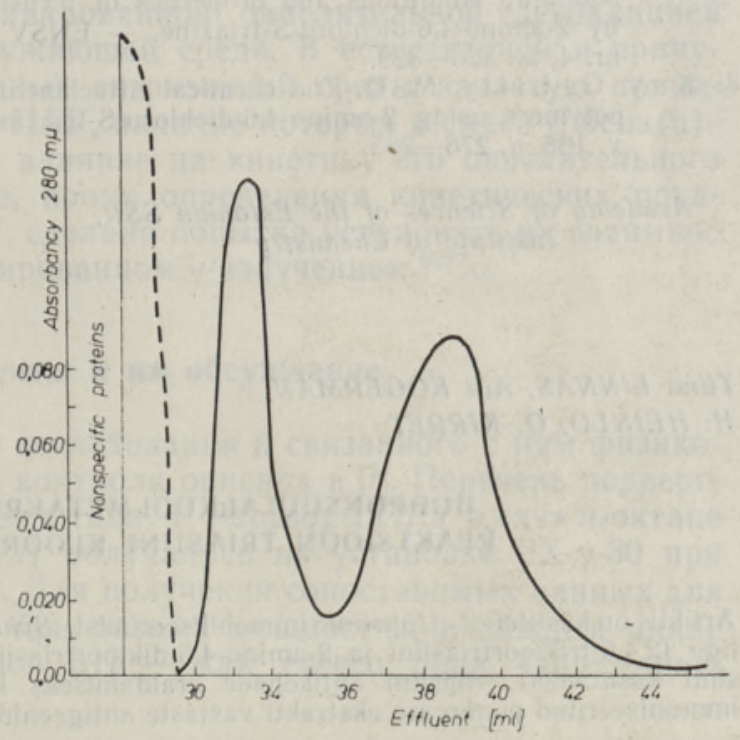
low substrate BAEE, are no more accessible to the large molecules of casein. The proteolytic activity of samples of trypsin bound to HMG with the aid of DCT is within 100 and $160 \mu \mathrm{m} \mathrm{NaOH}$ per $5 \mathrm{~min}$ (i. e., 5 to $9 \%$ relatively) and is stable enough.

Our data indicate the capacity of Spheron P-1000 activated with DCT to be lower than that of other carriers used for the quantitative assay of antibodies in rabbit serum. But taking into consideration the high properties of Spheron P-1000 under column conditions, its low capacity does not prevent using Spheron P-1000 in affinity chromatography of antibodies. The curve for eluation in Fig. 7 shows the possibility of using immobilized trypsin to isolate antibodies of trypsin from rabbit serum immunized with a suspension of tissue antigens of pancreas.

Our investigations led to the conclusion that the binding of biological molecules to HMG with the aid of DCT may be considered possible, with the necessity of using preparations of low-degree substitution. 


\section{Summary}

1. The activation reaction of hydroxyalkyl methacrylate gel Spheron P-1000 with chlorine derivates of triazine, i. e., TCT and DCT, has been investigated.

2. Optimal conditions of binding trypsin to HMG-activated chlorine derivates of triazine have been found.

3. Samples of the bound trypsin with a stable activity have been obtained by activating HMG with TCT and DCT.

4. The use of immobilized trypsin in the isolation of trypsin antibody from rabbit serum immunized with a suspension of tissue antigens of pancreas has been studied.

\section{REFERENCES}

1. Turková, O., Hubalková, O., Krivaková, M., Coupek, L. Affinity chromatography on hydroxyalkyl methacrylate gels. - Biochim. Biophys. Acta, 1973, v. 322 , p. $1-9$.

2. Fed oseyev, V., Pank, M., Mure1, A., Hein lo, H., Kirret, O. Optimal bounding conditions and properties of trypsin samples immobilized on Sephadex by 2-amino-4,6-dichloro-S-triazine. - ENSV TA Toim. Keem. Geol., 1977, kd.26, nr. 4 , lk. $326-329$.

3. K a y, G., L illy, M. D. The chemical attachment of chimotrypsin to water-insoluble polymers using 2-amino-4,6-dichloro-S-triazine. - Biochim. Biophys. Acta, 1970, v. 198 , p. $276-285$.

Academy of Sciences of the Estonian SSR, Institute of Chemistry

Received November 28, 1978

Tiina LINNAS, Aili KOGERMAN,

H. HEINLO, O. KIRRET

\section{HODROKSUOLALKOULMETAKRULAATGEELIDE REAKTSIOON TRIASIINI KLOORDERIVAATIDEGA}

Artiklis on käsitletud trüpsiini immobiliseerimist Spheron P-1000-le triasiini kloorderivaatide (2,4,6-trikloortriasiini ja 2-amino-4,6-dikloortriasiini) abil ning immobiliseeritud trüpsiini kasutamist trüpsiini antikehade eraldamiseks küülikute verest, keda eelnevalt on immuniseeritud pankrease ekstrakti vastaste antigeenidega.

Тийна ЛИННАС, Айли КОГЕРМАН,

Х. ХЕИНЛО, О. КИРРЕТ

\section{РЕАКЦИЯ ГИДРОКСИАЛКИЛМЕТАКРИЛАТНЫХ ГЕЛЕИ С ХЛОРПРОИЗВОДНЫМИ ТРИАЗИНА}

Установлено, что перспективным можно считать связывание биологически активных молекул с -OH-группами марки Spheron P-1000 при применении менее ядовитых реагентов - 2-амино- 4,6-дихлортриазнна и 2,4,6-трихлортриазина. Показана возможность использования иммобнлизованного трипсина для выделения антител трипсина из сыворотки крови кроликов, иммунизированных суспензией тканевых антигенов поджелудочной железы. 